\title{
OPTIMAL BACTERIAL DENSITY AND FERTILIZER DOSAGE FOR BIOREMEDIATION OF OIL CONTAMINATED SANDY BEACH: A CASE OF CILACAP, INDONESIA
}

\author{
YETI DARMAYATI ${ }^{1 *}$, HARPASIS S. SANUSI ${ }^{2}$, TRI PRARTONO ${ }^{2}$, \\ DWI ANDREAS SANTOSA ${ }^{3}$ and RUYITNO NUCHSIN ${ }^{1}$ \\ ${ }^{1}$ Marine Microbiology Laboratory, Research Center for Oceanography, Lembaga Ilmu Pengetahuan Indonesia \\ (LIPI/Indonesian Institute of Sciences), Jakarta 11048, Indonesia \\ ${ }^{2}$ Faculty of Fisheries and Marine Sciences, Institut Pertanian Bogor, Bogor 16680, Indonesia \\ ${ }^{3}$ Faculty of Agriculture, Institut Pertanian Bogor, Bogor 16680, Indonesia
}

Received 20 July 2016/Accepted 5 July 2017

\begin{abstract}
Bioremediation, involving biostimulation and/or bioaugmentation, is a promising method to overcome oil spills in Cilacap coastal waters. Cilacap coastal area has high risk on oil pollution. This study investigated the stimulatory effect of nitrogen concentration, bacterial density and the composition of bacterial culture in enhancing oil degradation in this area. The applications of 4 different concentrations of Slow Release Fertilizer (SRF) and 2 different densities of bacterial cells in the form of single (RCO/B/08_008) and mixed culture were employed in microcosm experiments for 28 days. The efficacy of combining bacterial culture and fertilizer application in various concentrations was also tested. Oil degradation, bacterial growth and environmental parameters were monitored periodically during the experiments. The results showed that oil degradation rate was more influenced by nutrient concentration (biostimulation) than bacterial number or culture composition (bioaugmentation) added. The efficacy of biostimulation in degrading oil was better than that of bioaugmentation. Biostimulation increased oil degradation up to 6.4 times higher than the control. The optimum of fertilizer concentration added was $7.5 \mathrm{mg} \mathrm{N} / \mathrm{g}$ (C:N ratio of $1,000: 75)$, which increased depletion rate both in biostimulation-only and the combination of biostimulation with bioaugmentation up to 6.4 and 7.5 times higher than the control, respectively. It is suggested that bioremediation of oil-contaminated sandy beach in Cilacap would be optimal by employing a combination of Slow Release Fertilizer at concentration having $\mathrm{C} / \mathrm{N}$ ratio $=1,000: 75$ and $\mathrm{RCO} / \mathrm{B} / 08$ _008 culture at density of $0.5 \times 10^{8}$ cells $/ \mathrm{mL}(100 \%$ homology with Alcanivorax sp. TE-9).
\end{abstract}

Keywords: Bacteria, bioremediation, coastal, fertilizer, Indonesia, oil, optimal

\section{INTRODUCTION}

Petroleum and its derived products are the major source of energy. To ensure long-term energy security for Indonesia, Pertamina (the Indonesian Oil and Gas Company) plans to expand and upgrade the refinery capacity plant in Dumai, Cilacap and Balongan. This expansion increases the pollution risk of Cilacap coastal waters due to oil spill. Therefore, there is a need to anticipate the impact of oil pollution in this area.

Bioremediation is considered to be a promising biological approach to overcome oil pollution in marine environment (Swannel et al.

* Corresponding author: yeti.darmayati@yahoo.com
1996; Jackson \& Purdue 1999; Munawar et al. 2007; Xu 2010). Bioremediation is basically an enhancement of biodegradation rate (Leahy \& Colwell 1990; Mrozika \& Seget 2010). Biological degradation process depends on several factors such as environmental conditions $(\mathrm{pH}$, temperature, dissolved oxygen/DO, degree of acclimation, accessibility of nutrients), numbers of microorganisms, types of microorganisms, cellular transport properties, chemical partitioning in growth medium and chemical structure of compounds degraded (Coartes $e t$ al. 2009; Lin et al. 2009).

To enhance the effectivity of bioremediation, those environmental factors are modified with applied nutrient supplementation 
(biostimulation) and introduction of specific competent strains or consortia of microorganisms (bioaugmentation) (Mrozika \& Seget 2010; Xu \& Liu 2010).

Few successes of implementing biostimulation and bioaugmentation strategies for remediating oil contaminated marine sediment in several tropical countries such as Singapore, Indonesia and India were reported (Xu et al. 2003; Xu et al. 2005; Munawar et al. 2007; Darmayati 2010; Darmayati et al. 2015; Pasumarthi \& Mutnuri 2016).

Field investigation in inter-tidal foreshore environment in Singapore and Indonesia demonstrated that fertilizer (Osmocote) was able to significantly enhanced hydrocarbonoclastic bacterial growth and increased the biodegradation of aliphatics and Polycyclic Aromatic Hydrocarbon (PAH) (Xu 2010; Darmayati 2010).

Osmocote is an anorganic Slow Release Fertilizer (SRF) coated by polymeric resin and consisted of water-soluble N-P-K at concentrations of $18 \%, 4.8 \%$ and $8.34 \%$, respectively. Petroganik, another fertilizer type, is organic nutrient having capability of stimulating soil microorganisms and enhancing oil degradation in oil contaminated Surabaya coastal area (Munawar et al. 2007).

Introduction of several selected bacteria in oil contaminated Cilacap coastal area through mesocosm study was proven to increase the rate of oil degradation up to 1.6 - 2.2 times higher than the rate of oil degradation in the control site (Darmayati et al.2015).

Until now, information is lacking on the optimal bacterial density and fertilizer dosage needed to increase oil degradation rate in Indonesian coastal area. This present study was aimed to study the stimulatory effect of nitrogen concentration, bacterial density and composition of bacterial culture to accelerate oil degradation in Cilacap coastal area. Cilacap coastal area is one of the most often areas polluted by oil spills.

\section{MATERIALS AND METHODS}

\section{Preparation of Bacterial Culture}

Three isolates of oil and PAHs degrading bacteria collected from Jakarta Bay sediment were provided by Marine Microbiology Laboratory,
Research Center for Oceanography, Lembaga Ilmu Pengetahuan Indonesia (LIPI/Indonesian Institute of Sciences). The isolates were RCO/B/08-008 (AB055207 Alcanivorax sp. TE-9, similarity 100\%), RCO/B/08-004 (AM905859 Pseudomonas balearica, similarity 99\%) and $\mathrm{RCO} / \mathrm{B} / 08-015$. The first two isolates were identified using partial sequencing of $16 \mathrm{~s}$ rRNA. The third isolate had not been sequenced yet; therefore, it only had a name code (Hatmanti \& Darmayati 2009). To prepare the mix cultured inoculum, the three strains were grown separately in marine agar at $30{ }^{\circ} \mathrm{C}$ for 72 hours. Each strain was harvested using Driglasky stick and sterilized saline water, then transferred into sterilized tube. The density of each strain was calculated using measurement of Optical Density (OD) and graph which correlate OD and bacterial cell number. Dilution method using sterilized saline water was conducted to make similar density. The mixed culture was formulated by mixing all the three strain cultures in the same volume to have a density ratio of $1: 1: 1$.

\section{Preparation of Artificially Oil Contaminated Sediment}

Oil contaminated sediment was prepared by spiking oil mousse of Arabian Light Crude Oil (ALCO) into the sample of sandy sediment and seawater collected from Cilacap coastal area. Oil mousse is a thick foamy mixture of oil and water which is formed when petroleum products are mixed with water due to the actions of wind and waves (Petropedia Inc 2017). Oil mousse used in this study was prepared by mixing Cilacap seawater and ALCO in $70: 30$ proportion using sterilized mixer for $15 \times 3$ minutes. Oil mousse of $4 \mathrm{mg}$ was spiked into $10 \mathrm{~g}$ sample of Cilacap sediment to achieve target concentration of $100,000 \mathrm{ppm}(100 \mathrm{mg} / \mathrm{g})$ of oil-contaminated sediment.

\section{Fertilizer Application}

Gramafix® fertilizer was used in this study. This fertilizer is a granular SRF fertilizer containing macro and micro nutrients (N:P:K:Mg:C:S:Micro element = 22:7:12:2:4:3:1). This fertilizer is commonly used for agricultural purposes. This fertilizer was selected due to their good performance in previous studies on oil 
Table 1 Treatment performed in each different experiment

\begin{tabular}{|c|c|c|c|c|}
\hline Experiment & Treatment & $\begin{array}{c}\text { Nitrogen } \\
\text { concentration } \\
(\mathrm{mg} / \mathrm{g})\end{array}$ & $\begin{array}{c}\text { Single culture } \\
\text { density } \\
(\text { cell } / \mathrm{mL})\end{array}$ & $\begin{array}{c}\text { Mixed culture } \\
\text { density } \\
(\text { cell/mL) }\end{array}$ \\
\hline \multirow[t]{5}{*}{ Biostimulation } & Control & \multicolumn{3}{|c|}{ no fertilizer and bacteria addition } \\
\hline & A & 1.88 & - & - \\
\hline & $\mathrm{B}$ & 3.75 & - & - \\
\hline & $\mathrm{C}$ & 7.50 & - & - \\
\hline & $\mathrm{D}$ & 15.00 & - & - \\
\hline \multirow[t]{5}{*}{ Bioaugmentation } & Control & \multicolumn{3}{|c|}{ no fertilizer and bacteria addition } \\
\hline & A & - & $0.5 \times 10^{8}$ & - \\
\hline & $\mathrm{B}$ & - & $1.0 \times 10^{8}$ & - \\
\hline & $\mathrm{C}$ & - & - & $0.5 \times 10^{8}$ \\
\hline & $\mathrm{D}$ & - & - & $1.0 \times 10^{8}$ \\
\hline \multirow[t]{9}{*}{ Combination } & Control & \multicolumn{3}{|c|}{ no fertilizer and bacteria addition } \\
\hline & A & 7.50 & $0.5 \times 10^{8}$ & - \\
\hline & $\mathrm{B}$ & 7.50 & $1.0 \times 10^{8}$ & - \\
\hline & $\mathrm{C}$ & 7.50 & - & $0.5 \times 10^{8}$ \\
\hline & $\mathrm{D}$ & 7.50 & - & $1.0 \times 10^{8}$ \\
\hline & $\mathrm{E}$ & 15.00 & $0.5 \times 10^{8}$ & - \\
\hline & $\mathrm{F}$ & 15.00 & $1.0 \times 10^{8}$ & - \\
\hline & G & 15.00 & - & $0.5 \times 10^{8}$ \\
\hline & $\mathrm{H}$ & 15.00 & - & $1.0 \times 10^{8}$ \\
\hline
\end{tabular}

degradation rate conducted in our laboratory (unpublished data).

There were 3 experiments conducted to determine the optimal fertilizer dosage for bioremediation i.e. biostimulation, bioaugmentation and combination between biostimulation and bioaugmentation.

In the biostimulation experiment, the applied fertilizer dosages were $1.88 \mathrm{mg} \mathrm{N} / \mathrm{g} ; 3.75 \mathrm{mg}$ $\mathrm{N} / \mathrm{g} ; \quad 7.50 \mathrm{mg} \mathrm{N} / \mathrm{g}$; and $15.00 \mathrm{mg} \mathrm{N} / \mathrm{g}$, respectively (Table 1). In the bioaugmentation experiment, there was no fertilizer applied (Table 1). In the combination between biostimulation and bioaugmentation experiment, the applied fertilizer dosages were $7.50 \mathrm{mg} \mathrm{N} /$ gand $15.00 \mathrm{mg}$ N/g (Table 1).

\section{Experimental Design}

To study the stimulatory effect of nitrogen concentration, bacterial density and the composition of bacterial culture in accelerating oil degradation, three experiments were conducted in Completely Randomized Design (Table 1).

The treatments applied were separate ALCOspiked sediment treatments amended with nitrogen using different fertilizer dosages and/or bacteria at different densities and compositions. One control treatment was set up as not having SRF fertilizer and no bacterial amendment.
Each microcosm in slurry form contained 15 $\mathrm{mL}$ seawater and $10 \mathrm{~g}$ oil-contaminated sediment having concentration of $100 \mathrm{mg} / \mathrm{g}$. A microcosm is an experimental unit in a $50 \mathrm{~mL}$ sterilized falcon tube.

Experiments were conducted for 28 days in an incubator shaker (having shaking speed of 100 $\mathrm{rpm})$ at room temperature $\left(28 \pm 2{ }^{\circ} \mathrm{C}\right)$.

Measurement of oil concentration was conducted in triplicates for each treatment at each sampling time. Measurements of supporting data such as numbers of bacterial cells, environmental factors (Dissolved Oxygen/DO, $\mathrm{pH}$ and salinity) and nutrient (nitrogen total) were conducted without any replications in each treatment at each sampling time.

For biostimulation experiment, measurements were conducted at day-0, day-14 and day-28 after exposure. Measurements of all parameters for the bioaugmentation and combination were conducted only at day- 0 and day-28 after exposure.

\section{Analysis of Oil, Bacteria and Environmental Parameters}

Oil concentration was measured from the slurry of the whole content of each microcosm. The extraction of oil was carried out using centrifugation and maceration methods with a 
mixture of Dichloromethane: n-hexana (1: 1) having proanalysis grade as a solvent. $\mathrm{Na}_{2} \mathrm{SO}_{4}$ was used to absorb the water remained in the extracted oil. Oil concentration in the slurry represented the concentration of oil in the treatment.

The numbers of bacterial cells on overlying water indicated the density of bacterial cells in porewater inside the microcosm. A detachment of bacteria was conducted by placing the microcosm in a vortex and shaking the vortex at $300 \mathrm{rpm}$ for 5 minutes. A subsample was drawn from the shaken microcosm. Counting of total bacterial cells was conducted using dilution method conducted on the subsample. Acridine Orange solution $(0.05 \%, 2.29 \mathrm{~mL})$ was added into the subsample. The supernatant was then filtered using polycarbonate membrane having pore size of $0.22 \mu \mathrm{m}$. The polycarbonate membrane was previously submerged in Sudan Black solution to obtain a contrast background. Direct counting of total bacterial cells was conducted under epifluorescent microscope (Hobbie et al. 1977).

To monitor the changes of environmental condition and nitrogen concentration in this microcosm system during experiment, one set of microcosm was provided for each purpose. The microcosm set was prepared similarly with the microcosm for measuring oil concentration and counting the numbers of bacterial cells. However, the numbers of microcosms were only prepared for one replication at each sampling time in each treatment. Measurements of salinity, $\mathrm{pH}$ and Dissolved Oxygen (DO) were carried out for the overlying water using hand refractometer (for measuring salinity), $\mathrm{pH}$ meter (Horiba, Navi D-54) and DO meter (Horiba, YSI 55), respectively.

Concentration changes of soluble nitrogen $(\mathrm{N})$ were measured by filtering, extracting and analyzing total nitrogen concentration for the whole content of microcosms. Persulfate digestion method was used for extraction prior to nutrient measurement ( $\mathrm{Zhu}$ et al. 2001). Total nitrogen concentration was determined using HACH DR 800 direct reading colorimeter using $\mathrm{HACH}$ proprietary reagents.

\section{Analytical Data}

Experiments were conducted using three independent replications for oil concentration. Percentage of oil depletion was calculated from oil concentration applied in the first and the third experiments after 28 days of incubation. Oil degradation data were analyzed using One Way ANOVA. The mean of the data were compared by Duncan Multiple Range Test (DMRT) at $p \leq$ 0.05. Kolmogorov-Smirnov test was used to test the normality of data, while the Levene Statistic test was used to test data heterogeneity. Statistical software used was SPSS 16.

Numbers of bacterial cells, nitrogen concentration and environmental data were provided as supporting data. These supporting data were only available for each treatment at each sampling time (without any replication). These supporting data were qualitatively analyzed.

\section{RESULTS AND DISCUSSION}

\section{Biostimulation}

Application of Slow Release Fertilizer (SRF) increased oil degradation rate in oil-contaminated coastal environment. However, the concentration of SRF should be carefully calculated to avoid a side effect in the oil-contaminated area, such as excessive algal growth. This study showed that SRF was effective to increase oil degradation. Applications of SRF at all tested $\mathrm{N}$ concentrations were able to increase degradation rate significantly (Table 2). Oil weight after being treated with SRF (for 28 days) ranged from 0.453 \pm 0.03 to $0.815 \pm 0.01 \mathrm{~g}$ per $10 \mathrm{~g}$ sediment. The remaining oil in the control was at the level of $1.185 \pm 0.06 \mathrm{~g}$ per $10 \mathrm{~g}$ sediment. The percentage of oil depletion in the SRF treatment was between $44.2 \pm 4.3 \%$ and $65.9 \pm 3.4 \%$. The percentage in the control treatment was only $13.3 \pm 2.6 \%$. There was statistically significant difference berween control and treatments.

Oil depletion and a numbers of bacterial cells were observed in the control. The results showed that oil degrading bacteria were available in this study site. However, the nutrients availability was insufficient for the growth of oil degrading bacteria due to the occurrence of oil spill. Nutrients concentration and hydrocarbon bioavailability are the key factors affecting oil biodegradation rates in oil-contaminated sites (Xu et al. 2005). Other studies proved that the growth of oil degrading bacteria and thus, oil degradation rate can be strongly increased by applying fertilizers containing inorganic $\mathrm{N}$ and $\mathrm{P}$ 
Table 2 The impact of nitrogen addition at various concentrations $(\mathrm{mg} / \mathrm{g})$ on oil depletion efficiency and bacterial density during 28 days exposure; including average and standard deviations of oil content and oil depletion $(\mathrm{n}=3)$, also bacterial number $(\mathrm{n}=1)$

\begin{tabular}{|c|c|c|c|c|c|}
\hline \multirow{2}{*}{$\begin{array}{c}\text { Nitrogen } \\
\text { concentration } \\
\text { added }(\mathrm{mg} / \mathrm{g})\end{array}$} & \multicolumn{4}{|c|}{ Oil content $(\mathrm{g})$} & \multirow{2}{*}{$\begin{array}{c}\begin{array}{c}\text { Oil depletion } \\
(\%)\end{array} \\
28 \mathrm{~d}\end{array}$} \\
\hline & $0 \mathrm{~d}$ & $7 \mathrm{~d}$ & $14 \mathrm{~d}$ & $28 \mathrm{~d}$ & \\
\hline 0 & $1.280 \pm 0.06$ & $1.289 \pm 0.02$ & $1.270 \pm 0.06$ & $1.185 \pm 0.06$ & $13.3 \pm 2.6^{\mathrm{e}}$ \\
\hline 1.88 & $1.280 \pm 0.06$ & $0.984 \pm 0.01$ & $0.787 \pm 0.09$ & $0.609 \pm 0.33$ & $51.9 \pm 3.4^{b}$ \\
\hline 3.75 & $1.280 \pm 0.06$ & $0.996 \pm 0.01$ & $0.904 \pm 0.09$ & $0.815 \pm 0.01$ & $31.0 \pm 3.6^{\mathrm{d}}$ \\
\hline 7.50 & $1.280 \pm 0.06$ & $1.007 \pm 0.01$ & $0.834 \pm 012$ & $0.453 \pm 0.03$ & $65.9 \pm 3.4^{\mathrm{a}}$ \\
\hline 15.00 & $1.280 \pm 0.06$ & $1.001 \pm 0.00$ & $0.809 \pm 0.02$ & $0.72 \pm 0.03$ & $44.2 \pm 4.3 \mathrm{c}$ \\
\hline \multicolumn{6}{|c|}{ Bacterial cells number (cells/mL) } \\
\hline & $0 \mathrm{~d}$ & $7 \mathrm{~d}$ & $14 \mathrm{~d}$ & $28 \mathrm{~d}$ & \\
\hline 0 & $6 . \mathrm{E}+07$ & $6 . \mathrm{E}+07$ & 1. $E+08$ & 2.E+08 & \\
\hline 1.88 & 2.E+08 & 2. $\mathrm{E}+08$ & 3. $\mathrm{E}+08$ & 9.E+08 & \\
\hline 3.75 & 8.E+07 & 8.E+07 & 3. $\mathrm{E}+08$ & 5. $\mathrm{E}+08$ & \\
\hline 7.50 & 2. $\mathrm{E}+08$ & 2. $E+08$ & 4. $\mathrm{E}+08$ & 1.E+09 & \\
\hline 15.00 & 2. $\mathrm{E}+08$ & 2. $\mathrm{E}+08$ & 3. $\mathrm{E}+08$ & 9.E+08 & \\
\hline
\end{tabular}

Note: The same letter $(\mathrm{a}-\mathrm{e})$ in the same column showed that the difference was not statistically significant $(p<0.05)$

(Swannell et al. 1996; Röling et al. 2002; Coulon et al.2007; Darmayati 2010).

There was no guarantee that higher fertilizer dosage resulted to higher oil degradation rate. Results of this study showed that excessive dosage of fertilizer inhibited the increase of oil depletion rate and bacterial numbers. Biostimulation treatments applying fertilizer with nitrogen concentration of 1.88 and $7.50 \mathrm{mg} / \mathrm{g}$ showed an increase in oil depletion efficiency and in bacterial growth. The oil depletion efficiency increased in a range of 2.3 - 5.0 times compared to that in control. The bacterial density were in a range of 4.1 - 4.6 times higher compared to that in control (Table 2).

However, the enhancement of oil degradation was only 3.3 times when nitrogen concentration increased up to $15.0 \mathrm{mg} / \mathrm{g}$. This result indicated that Carbon/Nitrogen $(\mathrm{C} / \mathrm{N})$ ratio of $1,000: 75$ and $1,000: 18.8$ provided better environment for the growth of oil degrading bacteria than the ratio of $1,000: 150$. Xu et al. (2003) mentioned that adding $0.8 \%$ of nitrogen $(\mathrm{C} / \mathrm{N}$ ratio $1,000: 33)$ and $1.5 \%$ of nitrogen $(\mathrm{C} / \mathrm{N}$ ratio $1,000: 61)$ of Slow Release Fertilizer (Osmocote) consisting of $18 \%$ nitrogen, $4.8 \%$ phosphor and $8.3 \%$ kalium $(\mathrm{w} / \mathrm{w})$ to oil contaminated sediment were sufficient to maximize the metabolic activity of biomass and to increase biodegradation of straight chain and branch chain of n-alkane, respectively.

There was high positive correlation between percentage of oil depletion and bacterial density. This was especially shown between the percentage of oil depletion obtained at day-28 and the bacterial density at day-14 $(r=0.87)$. Coefficient of determination of 0.77 showed that $77 \%$ of variations in the percentage of oil depletion were explained by bacterial density; while the remaining $23 \%$ of variations in percentage of oil depletion might be due to other factors such as nutrients and other environmental factors.

Until certain level, high oil concentration and high nutrient availability may increase bacterial growth. This study showed that bacterial density in microcosm with SRF application was 2.4-4.6 times higher than that in control at day-14 (Table 2). High bacterial density in this experiment represented high abundance of oil-degrading bacteria. Coulon et al. (2007) mentioned that $\mathrm{N}$ and $\mathrm{P}$ increased the abundance of oil degrading bacteria and total oil degradation. Our previous study showed also that microbial biomass increased and the growth rate of oil degrading bacteria was higher than total bacteria (Darmayati 2010). Population of oil degrading bacteria used oil as their source of energy and nutrient. Higher 
number of oil degrading bacteria led to higher rate of oil depletion.

\section{Bioaugmentation}

Bioaugmentation was able to increase oil degradation, both in single or mixed culture treatment. However, bioaugmentation contributed lower increase of oil degradation compared to the increase caused by biostimulation. Significant $(\phi<0.05)$ increase on the percentage of oil degradation caused by bioaugmentation ranged from $28.4 \pm 1.9 \%$ to $34.3 \pm 6.2 \%$ (Table 3), while the increase of oil degradation percentage caused by biostimulation ranged from $44.2 \pm 4.3 \%$ to $65.91 \pm 3.4 \%$ (Table 3).

This occurrence happened because the growth of oil degrading bacteria (hydrocarbonoclastic bacteria) was limited by nutrient insufficiency in the area of oil spill. $\mathrm{C} / \mathrm{N}$ ratio was higher than it should be when oil spill occurred and no added nutrient administered to the oil spill area.

Increase of bacterial density in each treatment was observed, but the increase was in a low rate. The highest numbers of bacterial cells $\left(8.2 \times 10^{8}\right.$ cells $/ \mathrm{mL}$ ) was observed at day-14 after treatment in the microcosm supplemented with mixed culture. This number was only 3.61 times higher than the bacterial number in control.

There was a strong positive correlation between numbers of bacterial cells and oil degradation percentage $(r=0.91)$ in this study. Oil degradation was supported by bioaugmentation with Alcanivorax sp. which was much more effective than nutrient addition (McKew et al. 2007). Oil pollution in Thames Estuary was in less density compared to that in Cilacap coastal area.
The Cilacap coastal area are heavily contaminated by oil due to industries and oil refinery establishments located in the area.

Introduction of mixed culture (Alcanivorax sp. TE-9, Pseudomonas balearica and RCO/B/08-015) and single culture (Alcanivorax sp.) did not give any significant effects on oil degradation rate in Cilacap coastal area. Different numbers of bacterial cells supplemented did not exhibit significant impact on oil depletion rate (Table 3). Treatment administering Alcanivorax sp. TE9TE-9 having density of $1.0 \times 10^{8}$ cells $/ \mathrm{mL}$ exhibited the highest oil degradation rate $(34.3 \%$ in 28 days), although it was not significantly different from the other three treatments (Table 3). Cilacap coastal area had high diversity of oil degrading bacteria and various enzymes needed for oil degradation were available in this area. Oil degrading bacteria available in Cilacap coastal area were Flexibacteraceae bacterium, Bacillus aquamaris, B. megaterium, B. pumilis, Halobacillus trueperi and Rhodobacteraceae bacterium (Syakti et al. 2013).

\section{Combination Treatment}

Combination treatment of biostimulation and bioaugmentation exhibited the best performance of oil bioremediation. In this experiment, oil reduction was observed in the range of $13.1 \pm$ $0.3 \%-74.6 \pm 3.6 \%$ at day-28 days after treatment. Bioaugmentation supplemented with SRF fertilizer having nitrogen concentration of $7.5 \mathrm{mg} / \mathrm{g}$ showed higher oil reduction than that in combination treatment supplemented with SRF fertilizer having nitrogen concentration of 15.0 $\mathrm{mg} / \mathrm{g}$ (Table 4). These results occurred both in single strain or mixed culture and also in high or

Table 3 The impact of bacterial amendment on oil depletion rate (at 28 days) and bacterial abundance (at 14 days); including average and standard deviations of oil depletion $(n=3)$

\begin{tabular}{cccc}
\hline Treatment & $\begin{array}{c}\text { Bacterial cell addition } \\
(\text { cells } / \mathrm{mL})\end{array}$ & Oil depletion $(\%)$ & $\begin{array}{c}\text { Bacterial cells number } \\
(\text { cells } / \mathrm{mL})\end{array}$ \\
\hline Control & 0 & $13.33 \pm 0.3 \mathrm{a}$ & $2.28 \mathrm{E}+08$ \\
\hline Single Culture & $0.5 \times 10^{8}$ & $28.37 \pm 1.9 \mathrm{~b}$ & $7.87 \mathrm{E}+08$ \\
& $1.0 \times 10^{8}$ & $34.34 \pm 6.2 \mathrm{~b}$ & $8.22 \mathrm{E}+08$ \\
\hline Mixed Culture & $0.5 \times 10^{8}$ & $30.53 \pm 4.8 \mathrm{~b}$ & $7.87 \mathrm{E}+08$ \\
\hline
\end{tabular}

Note: The same letter $(\mathrm{a}-\mathrm{b})$ in the same column showed that the difference was not statistically significant $(p<0.05)$ 
Table 4 Comparison of oil depletion percentage (at 28 days) and bacterial abundance (at 14 days) in oil contaminated sediment exposed by different treatment of $\mathrm{N}$ concentration and bacterial amendment for 28 days experiment

\begin{tabular}{ccccc}
\hline & Treatment & & Parameter measured \\
\hline Fertilizer & Culture & $\begin{array}{c}\text { Bacterial cell number } \\
\text { added }\end{array}$ & $\begin{array}{c}\text { Oil depletion } \\
(\%)\end{array}$ & $\begin{array}{c}\text { Bacterial density } \\
(\text { cells } / \mathrm{mL})\end{array}$ \\
\hline Control & Single & 0 & $13.1 \pm 0.3^{\mathrm{a}}$ & $2 . \mathrm{E}+08$ \\
\hline $\mathrm{N}=7.5 \mathrm{mg} / \mathrm{g}$ & & $0.5 \times 10^{8}$ & $74.6 \pm 3.6^{\mathrm{c}}$ & $1 . \mathrm{E}+09$ \\
& Mixed & $1.0 \times 10^{8}$ & $30.2 \pm 4.2^{\mathrm{f}}$ & $8 . \mathrm{E}+08$ \\
& & $0.5 \times 10^{8}$ & $64.9 \pm 1.0^{\mathrm{d}}$ & $1 . \mathrm{E}+09$ \\
\hline $\mathrm{N}=15.0 \mathrm{mg} / \mathrm{g}$ & $1.0 \times 10^{8}$ & $46.7 \pm 1.5^{\mathrm{e}}$ & $1 . \mathrm{E}+09$ \\
\hline & Single & $0.5 \times 10^{8}$ & $24.8 \pm 2.2^{\mathrm{c}}$ & $6 . \mathrm{E}+08$ \\
& Mixed & $1.0 \times 10^{8}$ & $38.7 \pm 0.3^{\mathrm{b}}$ & $9 . \mathrm{E}+08$ \\
& & $0.5 \times 10^{8}$ & $15.9 \pm 3.4^{\mathrm{a}}$ & $6 . \mathrm{E}+08$ \\
& $1.0 \times 10^{8}$ & $13.1 \pm 0.3^{\mathrm{a}}$ & $6 . \mathrm{E}+08$ \\
\hline
\end{tabular}

Note: Columns marked by the same letter (a to g) are not statistically significant different $(p<0.05)$. No replications for bacterial cells number

low bacterial density. This study confirmed that $\mathrm{C} / \mathrm{N}$ ratio of $1,000: 75$ was better than $1,000: 150$ for bacterial growth. Excessive nutrients concentration might suppress the growth of bacteria, whereas in combination treatments, nutrients concentration was lower, but sufficient for bacterial growth. Sufficient loading rates of nitrogen will be necessary to trigger biostimulation. According to Gibbs et al. (1975) approximately $4 \mathrm{mM}$ of nitrogen was required to breakdown $1 \mathrm{mg}$ of crude oil; phosphorus did not limit $\mathrm{P} / \mathrm{N}$ ratio to a minimum of 0.02 . Loading rates of nutrients below critical concentration would be a waste of resources; the same as excessive use which could promote secondary impacts such as harmful algal bloom and oxygen depletion (Bragg et al. 1994; Jackson \& Pardue 1999).

The combination of bioaugmentation and biostimulation approach by nitrogen amendment at moderate level was proven, in the laboratory and in the field, as the best approach for reducing oil in environment (Darmayati et al. 2015; Pasumarthi \& Mutnuri 2016). Our study in Cilacap coastal area using mesocosm approach confirmed that combination of bioaugmentationbiostimulation is the best strategy for cleaning up oil spills (Darmayati et al. 2015). Other studies in Goa (India) and Egypt supported this conclusion (Pasummarthi \& Mutnuri 2016; El-Borai et al. 2016).

\section{Enviromental Condition}

Environmental conditions ( $\mathrm{pH}$, temperature, dissolved oxygen, degree of acclimation, accessibility of nutrients) are among important factors in biological degradation processes, besides numbers of microorganisms, types of microorganisms, cellular transport properties, chemical partitioning in growth medium and chemical structure of degraded compounds (Coartes et al. 2009; Lin et al. 2009). In this study, the impact of nutrients addition into environment could be observed obviously such as the changes of salinity and DO levels during exposures time (Fig. 1).

Salinity was shown as an important factor in bacterial growth influencing oil biodegradation in this study. The addition of SRF fertilizer increased salinity depending on the added fertilizer concentration. SRF application at 150 $\mathrm{mg} \mathrm{N} / \mathrm{mLincreased} \mathrm{salinity} \mathrm{up} \mathrm{to} 65 \mathrm{ppt}$ (Fig. 1). The increase of salinity might be caused by Gramafix which contained high concentration of macronutrients (NPK), secondary macronutrients $(\mathrm{Mg}, \mathrm{S}, \mathrm{Ca})$ and micronutrients ( $\mathrm{Zn}, \mathrm{Fe}, \mathrm{Cl}, \mathrm{Mn}, \mathrm{B}, \mathrm{Bo}, \mathrm{Mo}$ ). The ratio of $\mathrm{Mg}, \mathrm{Ca}, \mathrm{S}$ and micronutrient was 2:4:3:1. High content of minerals in this SRF fertilizer seemed to play an important role in increasing the catalytic activity of enzymes produced by oil degrading bacteria. Cookson Jr (1995) mentioned that $\mathrm{Mg}^{2+}$ and $\mathrm{Ca}^{2+}$ 

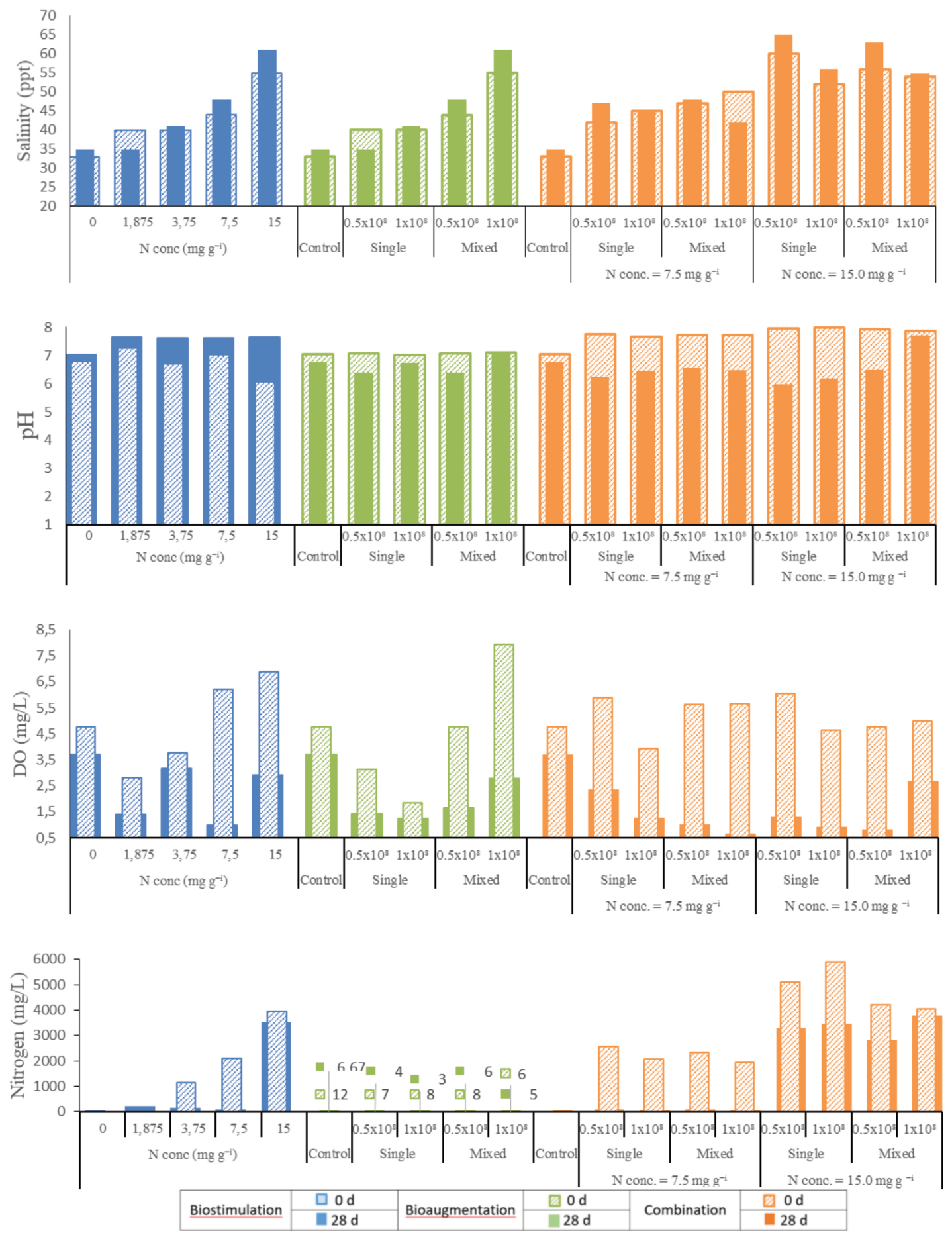

Figure 1 Environmental parameters condition at day- 0 and day-28 of experiments in three different bioremediation experiments

are metallic ions that can function as a co-factor in the catalytic enzyme activity of microbes.

In this study, the range of salinity during the experiment was $32-65$ ppt. This high level of salinity might still be tolerable by marine oildegrading bacteria, which was shown by the bacterial growth observed at day-14 (Table $3 \& 4$ ). Other study focused on biodegradation of crude oil by a mixed bacterial community isolated from marine sediment with varying concentrations of sodium chloride (Mille et al. 1991). Initially, the amount of degraded oil increased with increasing salt concentration, to a maximum level of 0.4 $\mathrm{mol} / \mathrm{LNaCl}$. Thereafter, the amount of degraded oil decreased with increasing salt concentration, probably because the salt-tolerance limit of the 
bacteria was reached. In this experiment, the salinity of seawater amended by fertilizer at nitrogen concentration of $7.5 \mathrm{mg} / \mathrm{g}$ sediment and $15.0 \mathrm{mg} / \mathrm{g}$ sediment increased up to $45-50$ ppt and $52-65 \mathrm{ppt}$, respectively. The salinity value in biostimulation and combination of biostimulation-bioaugmentation treatments was higher than control (Fig. 1).

These experiments were conducted in the range of Dissolved Oxygen (DO) value between $0.64-6.05 \mathrm{mg} / \mathrm{L}, \mathrm{pH}$ value of $5.52-8.19$ and salinity value of $32-65$ ppt (Fig. 1). During the experiments, DO value was always getting lower along with incubation time and increased numbers of bacteria. Dissolved Oxygen was sufficiently available to be consumed by bacteria to metabolize oil. No aeration was provided during the experiments. The oxidation of the substrate by oxygenases during the process of aerobic respiration, for which molecular oxygen is required, occurs in the initial steps of catabolism of aliphatic, cyclic and aromatic hydrocarbons by bacteria and fungi (Leahy \& Colwell 1990).

$\mathrm{pH}$ value during the experiment was in the range of 5.56-7.99 which was optimal range for biodegradation process. Bioremediation treatment used in this study provided good results for reducing oil in the marine environment.

Nitrogen availability in control was in natural condition, which was in the range of $7-12 \mathrm{mg} / \mathrm{L}$. Addition of fertilizer increased nitrogen availability in microcosm. However, available nitrogen observed in moderate concentration of nitrogen $(7.5 \mathrm{mg} / \mathrm{g})$ were higher than that in high concentration of nitrogen $(15.0 \mathrm{mg} / \mathrm{g}$ ) (Fig. 1). This might be caused by excessive nitrogen which suppressed the growth of bacteria in the environment with having nitrogen concentration of $3,943-5,900 \mathrm{ppm}$, so that the numbers of bacterial cells were lower and oil degradation rate was slower than the combination treatment (at nitrogen concentration of 1,940-2,090 ppm).

\section{CONCLUSIONS}

Oil depletion rate was influenced by the numbers of bacterial cells and nutrients concentration. Efficiency of oil degradation in biostimulation treatment was better than that in bioaugmentation treatment. However, the highest oil degradation rate was observed at a combination of bioaugmentation-biostimulation treatment. This treatment was able to increase oil degradation rate up to 7.5 times higher than that in control. In addition, the salinity range of $32-$ 65 ppt caused by fertilizer addition might still be tolerable for marine oil-degrading bacteria. Bioremediation of oil contaminated sandy beach in Cilacap would be optimal by employing a combination of Slow Release Fertilizer $(\mathrm{G})$ at $\mathrm{C} / \mathrm{N}$ ratio of $1,000: 75$ and $\mathrm{RCO} / \mathrm{B} / 08+008$ culture having bacterial density of $0.5 \times 10^{8}$ cells/mL (100\% homology with Alcanivorax sp. TE-9).

\section{ACKNOWLEDGEMENTS}

This research was supported by the Research Centre Oceanography-Indonesian Institute of Sciences under DIPA 2011 and the Ministry of Research and Technology, Indonesia. The first author thanks Linda Safitri, Surahman, Noor Farida and Azhar Zaki Nugroho who assisted in technical matters.

\section{REFERENCES}

Bragg JR, Prince RC, Harner EJ, Atlas RM. 1994. Effectiveness of bioremediation for the Exxon-Valdez oil-spill. Nature 368:413-18.

Coartés GC, Carrillo T, PeñascoI Z, Avila JR, Aké LQ, Cruz JM, Lora PO. 2009 Microcosm assays and taguchi experimental design for treatment of oil sludge containing high concentration of hydrocarbons. Bio Technol 100:5671-7.

Cookson Jr JT. 1995. Bioremediation engineering: Design and application. New York (US): McGrawHill, Inc. p. 524 .

Coulon F, McKew BA, Osborn AM, McGenity TJ, Timmis KN. 2007. Effect of temperature and biostimulation on oil-degrading microbial communities in temperate estuarine waters. Environ Microbiol 9:177-86.

Darmayati Y. 2010. Bioremediation of crude oil contaminated sediment using slow fertilizer: hydrocarbonoclastic bacteria population dynamics. IJMS 2:462-76.

Darmayati Y, Sanusi HS, Prartono T, Santosa DA, Nuchsin R. 2015. The effect of biostimulation and biostimulation-bioaugmentation on biodegradation of oil-pollution on sandy beach mesocosm. International Journal of Marine Science 5(27):1-11. DOI:10.5376/ijms.2015.05.0027. 
El-Borai A, Eltayeb KM, Mostafa AR, El-Assar S. 2016 Biodegradation of industrial oil-polluted wastewater in Egypt by bacterial consortium immobilized in different types of carriers. Pol J Environ Stud 25(5):1901-9.DOI: $10.15244 /$ pjoes/62301.

Gibbs CF, Pugh KB, Andrew AR. 1975. Quantitative studies on marine biodegradation of oil. II. Effect of temperature. Proceedings of Royal Society London Series B. Biological Science. Jan 2. 188:83-94. London (UK): Harrison \& Sons.

Hatmanti A, Darmayati Y. 2009. Characterization and phylogenetic analysis of potential oil and PAH degrading bacteria from Jakarta Bay waters. In: Nuryanto A, Budisantoso I, Ardli ER, Prabowo RE, editors. Proceeding of Biology National Seminar 2009. p. 576-81. [in Indonesian].

Hobbie JE, Daley RJ, Jasper S. 1977. Use of nucleopore filters for counting bacteria by fluorescence microscopy. Appl Environ Microbiol 3:1225-8.

Jackson WA, Pardue JH. 1999 Potential for enhancement of biodegradation of crude oil in Lousiana salt marshes using nutrient amendments. Water, Air, and Soil Pollution 109:343-55.

Leahy JG, Colwell RR. 1990 Microbial degradation of hydrocarbons in the environment. Microbiol Rev 53(3):305-15.

Lin TC, Shen FT, Chang JS, Young CC, Arun AB, Lin SY, Chen TL. 2009. Hydrocarbon degrading potential of bacteria isolated from oil-contaminated soil. J Taiwan Inst Chem Eng 40:580-82.

McKew BA, Coulon F, Yakimov MM, Denaro R, Genovese M, Smith CJ, ... McGenity TJ. 2007. Efficacy of intervention strategies for bioremediation of crude oil in marine systems and effects on indigenous hydrocarbonoclastic bacteria. Env Microbiol 9:1562-71. DOI:10.1111/j.1462-2920.2007.01277.

Mille G, Almallah M, Bianchi M, van Wambeke F, Bertrand JC. 1991. Effect of salinity on petroleum biodegradation. Frensenius J Anal Chem 339: 788-91.

Mrozika A, Seget ZP. 2010. Bioaugmentation as a strategy for cleaning up of soils contaminated with aromatic compounds. Microbiol Res 165:363-75.

Munawar, Mukhtasor, Surtiningsih T. 2007. Oil spill bioremediation by organic nutrient biostimulation method in East Surabaya coastal. Periodical of Biological Research 13:91-6. [in Indonesian].

Pasumarthi R, Mutnuri S. 2016 Horizontal gene transfer versus biostimulation: a strategy for bioremediation in Goa. Mar Pol Bull 113 1-2:271-6. Available from: https://doi.org/10.1016/j.marpolbul.2016. 09.04.4.

Petropedia Inc [Internet]. 2017. Mousse. [Updated 2017; cited 2017 Dec 2017]. Available from: https://www.petropedia.com/definition/7694/mo usse

Röling WFM, Milner MG, Jones DM, Lee K, Daniel F, Swannell RJP, Head IM. 2002. Robust hydrocarbon degradation and dynamics of bacterial communities during nutrient-enhanced oil spill bioremediation. Appl Environ Microbiol 68(11):5537-48.

Swannell RPJ, Lee K, McDonagh M. 1996. Field evaluations of marine oil spill bioremediation. Microbiol Rev 60:342-65.

Syakti AD, Yani M, Hidayati NV, Siregar AS, Doumenq P, Sudiana IM. 2013. The bioremediation potential of hydrocarbonoclastic bacteria isolated from a mangrove contaminated by petroleum hydrocarbons on the Cilacap Coast, Indonesia. Bioremediat J 17(1):11-20. DOI:10.1080/10889868. 2012.731446.

Xu R, Lau ANL, Lim YG, Obbard JP. 2005. Bioremediation of oil contaminated sediments on an inter-tidal shoreline using a slow-release fertilizer and chitosan. Mar Pollut Bull 51:1062-70.

Xu Y, Liu M. 2010. Bioremediation of crude oilcontaminated soil: Comparison of different biostimulation and bioaugmentation treatments. J Hazard Mater 183: 395-401.

Xu R, Obbard JP, Tay ETC. 2003. Optimization of slowrelease fertilizer dosage for bioremediation of oilcontaminated beach sediment in a tropical environment. Water Sci Technol 47(1):303-8.

Xu YM. 2010 Bioremediation of crude oil-contaminated soil: comparison of different biostimulation and bioaugmentation treatments. J Hazard Mater 183:395-401.

Zhu X,Venosa A, Suidan MT, Lee K. 2001 Guidelines for the bioremediation of marine shorelines. Cincinnati (US): US Environmental Protection Agency. 